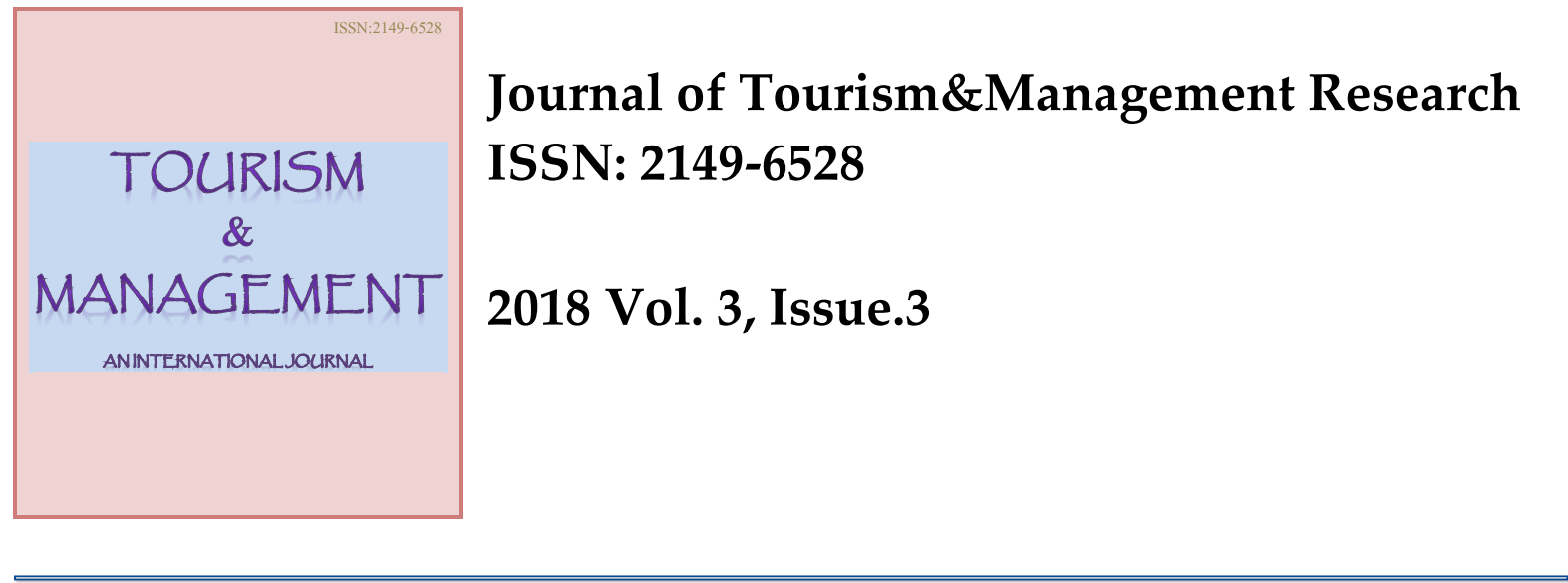

\title{
The Effects of Displacement of Movie Setting on Tourists' Satisfaction with Movie Induced Tourism
}

\begin{abstract}
Movies that use wildlife, picturesque landscape and traditional culture as the major story plot have increasingly been used to promote tourism destinations. This practice is known as Movie Induced Tourism (MIT). This paper examines the influence of displacement of movie setting on the tourists' satisfaction with MIT. It is based on a study that utilised both descriptive and explanatory research designs and covered filming locations at Karen Blixen Museum and Samburu for the movies Out of Africa and The White Maasai, respectively. The target population comprised 660 foreign tourists, who visited the Karen Blixen Museum and Samburu. Simple random sampling technique was used to select a sample size of 345 research participants. Primary data was collected using questionnaires whereas secondary data was collected from published materials and e-materials. Descriptive statistics (percentages, median, means and standard deviations) and multiple regressions were used to analyse the data collected. The study findings confirm that that displacement of movie setting $(\beta 1=-$ $0.477, \mathrm{p}=0.000$ ) has a negative and significant relationship with tourist satisfaction. Through the displacement of the movie setting, a majority of the tourists were dissatisfied with MIT since what was being portrayed in the movies was not entirely accurate.
\end{abstract}

Keywords: Displacement, Movie induced tourism, Movie setting, Tourist satisfaction, Kenya JEL Classifications: Z3, M1, M31.

Submitted: 26/07/2018; Accepted:20/11/2018

Justus Muchiri, PhD. (Corresponding Author). School of Tourism and Natural Resource Management Maasai Mara University, Kenya. Current Postal address: 861-20500 Narok, Kenya.

E-mail: kangojustus@yahoo.com / Mobile: +254721691544.

Rita Wairimu Nthiga, PhD. School of Tourism, Hospitality and Events Management Moi University, Kenya. Current Postal Address: P.O Box 3900, 30100 Eldoret, Kenya.

Email: rita.wairimu@gmail.com Mobile Tel: +254 721758459 


\section{Introduction}

Tourist satisfaction is related to the mental state of the tourist rather than the physical state. It refers to the pleasure of the tourist after visiting any particular tourist destination (Khan et al., 2013). Several empirical studies (Bigne et al., Chen \& Chen, 2010; Gallorza \& Saura, 2006; 2005; Philips \& Baumgarther, 2002; Rojas \& Camerero, 2008; Westbrook \& Oliver, 1991) have been carried out aimed at examining attributes of tourist satisfaction. From a theoretical perspective, pleasure and arousal dimensions positively influence tourist satisfaction (Bigne' et al., 2005). Other studies argue that there is a relationship between tourists' emotion and their satisfaction (Brook \& Oliver, 1991; Phillips \& Baumgarther, 2002; Rojas \& Camerero, 2008). Elsewhere, Chen and Chen (2010) and Gallorza \& Saura, (2006) affirm personal values, perceived past experience and quality as a direct determinant of satisfaction. While in a destination context, tourist satisfaction is affected by lodging, food, shopping, attractions, activities and event, environment, accessibility, price, culture, climate and image, nature and lifestyle, history, service, tourist facilities, sanitation, nightlife and value for money and employee (Akama and Kieti, 2003; Chi and Qu, 2008; Heung and Cheng, 2000; Kozak and Rimmington, 2000), in the hospitality research, service, food, menu diversity, hygiene, convenience and location, noise, service speed, price and value, facilities, and atmosphere are found to affect tourist satisfaction (Liu \& Jang, 2009; Yuksel \& Yuksel, 2002).

In this regard, Kenya has attracted various prominent filmmakers due to its great variety of wild animals, picturesque sceneries, exquisite cuisine, welcoming people and diverse culture (Brand Kenya Board, 2013). These amongst other attractions draw film makers to Kenya. Consequently, more than 80 movies have been entirely filmed and produced in Kenya (Muchiri, 2013). Some of these have turned out to be great box office hits and won various international accolades. The most prominent movies are Out of Africa, Master of the Game, Kitchen Toto, White Maasai, First Grader, Walking with Lions, King Solomon's mines, The Wilby Conspiracy, Rise and Fall of Idi Amin, The Colour Purple (Second Unit), The Life of Hemmingway, Nowhere in Africa, Cry Freedom, White Mischief and I Dream of Africa among others.

The movie Out of Africa is perhaps the greatest of all movies made in Kenya (True Love Magazine, 2006). The success and extensive view of the movie gave the Kenyan tourism a strong boost. A majority of people who watched the movie made their visit to Kenya to see what they had watched in the movie. The movie blends Kenya's culture, wildlife and spectacular landscape in a story plot. Moreover, the movie displays what tourists can see in Kenya, including welcoming people and prevailing peace. The image is in contrast to the image of Kenya portrayed in western media as a corrupt and insecure country. However, many movies portray a negative image of Kenya such as Paradise Love that depicts the Kenyan coast as a haven for sex tourism in East Africa. Various award-winning series have been made in Kenya due to its amazing landscapes, sceneries and rich diversity of wildlife. Some of the TV programmes filmed in Kenya include BBC Natural history, Discovery channel amongst many world-reknown productions. Maasai Mara has for decades been staging the Cat Diary, a BBC production which follows the lives and times of Maasai Mara's famed predators (Brand Kenya Board, 2013).

Bolan et al. (2011) in their work, "We have seen it in the movies; let's see if it is true," used authenticity and displacement to address a gap in the film induced literature. The study found out that authenticity is important to film tourist mostly when displacement occurs. In another study by Roesch (2009), the findings assert that in order to improve film location encounter and experience, basic infrastructure like signage, a commemorative plaque, photo boards and guides need to be provided. Unlike Kim (2012), Bolan et al. (2011) and Roesch (2009), this research took different dimensions and utilized displacement (authenticity) of movie setting to explore its effects on tourist satisfaction with movie induced tourism. This study utilized the theory of Expectancy Disconfirmation (Oliver, 1977) and the American 
Customer Satisfaction Index (ACSI). While the theory of Expectancy Disconfirmation has four main constructs: expectations, performance, disconfirmation, and satisfaction (Oliver, 1977). ACSI is based on six constructs; customer satisfaction as a central construct, three antecedents (customer expectation, perceived quality and perceived value) and two outcomes (complains behaviour and customer loyalty). Generally, a tourist's expectation is created by the anterior information accessed before a visit to a given location. In the case study, tourists' expectation is enhanced by their prior viewing of movies on a given destination. However, movie induced tourism should not just be viewed as a destination motivator, economic booster or promoter of worldwide tourist destinations but also as an avenue for new and favoured destinations to come to the fore. In the case of Kenya, for example, Out of Africa assisted in showcasing the beautiful beaches, magnificent landscape, unmatched wildlife and Kenya's diverse culture. The success of the movie resulted in increased foreign earnings of approximately $\$ 350$ million in 2009 . Despite movie induced tourism being on the rise, the extent to which displacement of movie setting affects tourists' satisfaction is still unknown. In this regard, there is a need to establish the effect of displacement of movie setting on tourists' satisfaction in movie induced tourism. Thus the current study aimed to investigate the effects of displacement of movie setting on tourists' satisfaction with movie induced tourism.

\section{Literature Review}

\subsection{Displacements of the Movie Setting and Tourist Satisfaction with MIT}

Early research on film tourism, such as Tooke and Baker (1996) noted that often the filmed location is not adequately represented and this scenario (displacement) makes it difficult for the viewers to differentiate between illusion and reality. As a result, what the tourist expects to see and what they eventually see and experience is entirely different. Although several studies including Beeton (2005), Hudson and Ritchie (2006) and Shandley et al. (2006) made reference to the displacement theory, it is only a study by Bolan, Boy and Bell (2011) on, "We've seen it in the movies, let's see if it's true" have made detailed research on this displacement.

According to Butler (1990), peoples' understating of the world geography is often falsified, particularly if it is based on what they get from media sources such as fictional literature and movies. For example, 'The Lord of the Rings' portrayal of New Zealand gives a tourist a simulation of cultures and landscapes that may not take into account the specific historical facts and stories of the portrayed places and the learning of the people. A majority of films are based on falsehood since they are not filmed in the locations they claim to be. As a result, they give a sense of the destination which could be totally different from what is the reality. In other words, what is offered distorts what one can find at the actual place (Butler, 1990). As a consequence, there is overwhelming evidence that visitors to film sites are disappointed when they do not see exactly what was portrayed on the screen (Beeton, 2005).

\subsection{Authenticity in Film Tourism}

Bolan et al. (2011) underscore the importance of authenticity in film tourism especially in light of displacement. Furthermore, the authentic experience offers tourists the chance to not only be personally involved in the natural context and daily life but also to see the arts, crafts and facts (McIntosh, 2004). Several studies consider authenticity as a crucial destination dimension because it is one of the primary factors that pull tourists to a destination. (Chhabra, 2010; Kolar \& Zabkar, 2010). A tourist's view of the authenticity of a particular tourist attractions site can be a crucial factor in determining their decision to travel to that destination (Kolar \& Zabkar, 2010). Hall (1995) and Beeton (2001) have shown that tourists desire to visit a place is greatly influenced by the images that they have seen. Goulding (2000) identified three types of visitors as far as authenticity is concerned: aesthetic, existential and 
social visitors (table 1). Aesthetic visitors look at history through the lenses of art, existential visitors treasure artefacts, enjoyment and escape that a venue offers them while social visitors put learning and social experience above everything else. They like purchasing souvenirs from museums and curio shops. Existential authenticity is activity-based, not object-based and can be grouped into two categories: interpersonal and intrapersonal. It may be hard for some tourist to precisely identify the thrill that they are seeking (Balon \& Williams, 2008). As a consequence, a tourist can build false and unrealistic expectations of a destination based on untruthful information resulting in great dissatisfaction after the visit.

Table 1: Forms of authenticity in the tourism sector.

\begin{tabular}{lll}
\hline Nature & Motivation & Output/ Experience \\
\hline Object-based & $\begin{array}{l}\text { Comes from a craving to visit } \\
\text { authenticity }\end{array}$ & $\begin{array}{l}\text { One gets to enjoy real sites, } \\
\text { arts, objects, crafts and } \\
\text { artefacts and buy souvenirs }\end{array}$ \\
experience.
\end{tabular}

Existential-based Activity-based and fuelled by the need authenticity to escape the boredom of everyday life to get in touch with true self. Selfactualization
One gets to sample great places and escape experience in an authentic location

Source: Kolar and Zabkar (2010).

Film-induced tourists have great similarities despite the diferent film genre they watch; they long to visit the ideal locations they have watched in films. According to Roesch (2009), going to real places helps them to get a feel of the real and tangible of what they have watched. For example, tourists get a chance to experience reality and authenticity by visiting a real location such as a cafe or a restaurant featured in a movie. Their emotional attachment to such a place means that they attach a new meaning to it. They experience the restaurant in a whole different and more emotional way than an ordinary visitor to that eatery would (Sellgren, 2011).

\subsection{Tourists' Expectations}

Tourists' expectations are informed by the images they see before making the trip. Indeed, according to Gunn (1988), the image that one has of a venue is a key factor in choosing the destination to visit. However, those with limited experience of their own of a destination rely on what they see in movies and films. Elsewhere, Zeithaml et al. (1993) assert that tourists' expectations are based on any consideration such as other people's opinions and pre-purchase beliefs. Chen and Chen (2010) argue that tourist satisfaction happens when the pre-travel expectations are matched by post-travel experience. A gratified tourist is one whose pre-travel expectations are matched by the post-visit experience. Nonetheless, Yuksel and Rimminton (1998) observe that measuring tourist experience before service delivery has many weaknesses, mainly when expectations are based on unfair comparisons and not on the reality on the ground.

Several researchers (Beeton, 2004; Iwashita, 2006) have mentioned the dissonance between films associated image and the real destination image, and argued that many films are not made in the locations in which the story is set, and thus the image of a place presented may not be an accurate portrayed of the destination in reality. Therefore, the authenticity of the place featured on screen is also an issue in film-induced tourism. Beeton (2005) and Roesch (2009) observe that tourists are well aware of the differences between the locations in the movie and the real locations; therefore, they do not expect an authentic experience. Wang 
(2007) notes that tourists who are aware of runaway productions and the differences between the movie set and reality, tend to have lower expectations and thus more satisfied with their location visits than those who do not know about runaway productions and computer generated parts.

Likewise, visitors to some sites have been disappointed that the community does not behave or dress in the manner described in a film. There is also the issue of mistaken identity, where a story may be set in a particular region, but filmed somewhere else (Jones \& Smith, 2005). According to Beeton (2001) and Croy and Walker (2003), when the location appears different than how it is portrayed in the film, there may be a loss of visitor satisfaction. As Iwashita (2006) argues, visitors can find the fulfilment of their emotional investment. The risk of being disappointed is therefore much more significant if the location has been substituted or a building no longer looks as they did in a programme or movie.

\section{Methodology}

The study areas included Samburu County and the Karen Blixen Museum where the two featured movies Out of Africa, and the White Maasai were filmed and went on to become great box office success stories; they won several international awards and helped to increase tourist numbers coming to Kenya. The study sought to establish whether the displacement of a movie setting can positively or negatively affect tourist satisfaction with MIT. The study used both qualitative and quantitative methods to gather data and adopted both explanatory and descriptive research designs.

The study sought information on the experience of every tourist who visited the filming locations for the two movies in Kenya, the number of trips they have made, those who watched the movie(s) and how the movies influenced their decision to visit the filming locations. They were also asked to state how they got information to plan their tour. The study targeted foreign tourists visiting Karen Blixen museum and Samburu county and had watched either of the movies and were touring the filming locations. The study also relied on trip advisor blogs to sample comments by tourists who had visited the location before undertaking this study. 658 bloggers who had voiced their views on filming locations were also interviewed. The blog's exploration helped to minimise inaccuracies and bias by tourists and aided in obtaining certain views from the vast majority of the population.

The simple random sampling method was used to identify respondents at Samburu County and Karen Blixen museum. This sampling technique was used to enhance the external validity of the research. A total of 354 foreign tourists and 248 bloggers were selected. The study used questionnaires and document analysis to collect data.

Data collected was first subjected to descriptive statistics (including frequencies, percentage, distribution median, mean and standard deviation) and multiple regression analysis was performed to establish whether there was a significant relationship between displacement and satisfaction at the level of $\alpha=0.05$.

\section{Results}

\subsection{Descriptive Statistics}

The research findings (see Table 2) revealed that 55\% (122) of the respondents got the information to plan their trip from friends or relatives, $45.9 \%$ (109) from the internet, $14.9 \%$ (33) from the media (TV, Radio, Movies and print media), 13.5\% (30) from travel agency/tour operator, $6.3 \%$ (14) from work/NGO/school and 3.6\% (8) from brochures.

Table 2: Source of Information before taking the Tour.

\begin{tabular}{lcc}
\hline Source & Frequency & Percent \\
\hline Tour operator & 30 & 13.5
\end{tabular}




\begin{tabular}{lcc} 
Relatives/ friends & 122 & 55 \\
Carriers/Airlines & 0 & 0 \\
Mass Media & 33 & 14.9 \\
Internet & 102 & 45.9 \\
Catalogue & 8 & 3.6 \\
Other sources( school, NGO/Work) & 14 & 6.3 \\
\hline
\end{tabular}

The results (see table 3) related tourists' expectations on the movie setting showed that the tourists expected first, the location of filming and objects used to be real (mean $=5.09, \mathrm{SD}=$ 1.467 ); second, they should get closer to the real location of filming (mean $=4.9$; $\mathrm{SD}=$ 1.566); third, there should be resemblance of scenes in the movie The White Maasai and Out of Africa and the actual museum/site of filming (mean $=5.31$; SD $=1.751$ ) ; fourth, the overall site of filming of Out of Africa and The White Maasai and the impressions in the museum/site should be very inspiring (mean $=5.37$; $\mathrm{SD}=1.696$ ); fifth, the facts about the locations should be true/real as it is in the movies Out of Africa and The White Maasai(mean = 5.33; $\mathrm{SD}=1.624)$; sixth, they should relate the movies Out of Africa and The White Maasai storylines and the actual location experience (mean $=5.4 ; \mathrm{SD}=1.671$ ); and finally, they should acquire a unique experience $($ mean $=5.55 ; \mathrm{SD}=1.444)$.

Table 3: Tourists' Expectations of the Karen Blixen Museum and Samburu.

\begin{tabular}{|c|c|c|c|c|}
\hline Scale Item & Mean & SD & Skewness & Kurtosis \\
\hline The filming locations and objects should be authentic. & 5.09 & 1.467 & -1.087 & 1.221 \\
\hline I need to get to/ closer to the real filming locations. & 4.9 & 1.566 & -0.612 & -0.009 \\
\hline $\begin{array}{l}\text { There ought to be a resemblance of scenes depicted in } \\
\text { Out of Africa and the tangible museum where it was } \\
\text { filmed. }\end{array}$ & 5.31 & 1.751 & -1.332 & 1.016 \\
\hline $\begin{array}{l}\text { The general filming sites of The White Maasai and Out } \\
\text { of Africa should be very inspiring. }\end{array}$ & 5.37 & 1.696 & -1.542 & 1.717 \\
\hline $\begin{array}{l}\text { The facts about the destination should be real as it is } \\
\text { depicted in the movies Out of Africa and The White } \\
\text { Maasai. }\end{array}$ & 5.33 & 1.624 & -1.221 & 0.939 \\
\hline $\begin{array}{l}\text { I should be able to relate the movies The White Maasai } \\
\text { andOut of Africa's storylines and the actual location } \\
\text { experience. }\end{array}$ & 5.4 & 1.671 & -1.721 & 2.204 \\
\hline I should acquire a unique experience. & 5.55 & 1.444 & -0.904 & 0.038 \\
\hline
\end{tabular}

Note: $\mathrm{SD}=$ Standard Deviation.

The study assessed the experiences of tourists after they visited the actual movie setting. The $\mathrm{R}$ results in table 4 indicate that the location of filming and objects used are real (mean = 5.65; $\mathrm{SD}=0.989$ ). It is possible to get closer to the real location of filming (mean $=5.34 ; \mathrm{SD}$ $=1.361)$. There is similarity and resemblance of scenes shown in the movies; Out of Africa and The White Maasai and the real museum ( filming location) (mean $=5.54$; $\mathrm{SD}=0.833$ ). The filming site of The White Maasai and Out of Africa and the real museum are very inspiring (mean $=5.7 ; \mathrm{SD}=0.858$ ). All information and facts about the museum are real and authentic as depicted in Out of Africa and The White Maasai (mean = 5.9; SD =0.681). They can connect the movies Out of Africa and The White Maasai storyline and the actual location 
experience $($ mean $=5.97 ; \mathrm{SD}=0.899)$ and they have acquired a unique experience after visiting the filming location $($ mean $=6.01 ; \mathrm{SD}=0.724)$.

Table 4: Experiences of Tourists in Karen Blixen Museum and Samburu.

\begin{tabular}{lcccc}
\hline Scale Item & Mean & SD & Skewness & Kurtosis \\
\hline The location of filming and objects used are real. & 5.65 & 0.989 & -1.267 & 3.536
\end{tabular}

It is possible to get closer to the real filming location of a movie.

$\begin{array}{llll}5.34 & 1.361 \quad-1.814 & 3.755\end{array}$

There is a connection between the scenes Out of Africa and The White Maasai and the actual museum/site of filming.

$\begin{array}{llll}5.54 & 0.833 & -0.614 & 1.882\end{array}$

The filming site of Out of Africa and The White Maasai and the impressions in the museum/site are very inspiring.

$\begin{array}{llll}5.7 & 0.858 & -1.629 & 2.615\end{array}$

The information and facts about the museum are real and authentic as portrayed in Out of Africa and The White Maasai.

$5.9 \quad 0.681 \quad-0.041 \quad-0.428$

I can connect between the movies Out of Africa and The White Maasai storyline and the actual location experience.

$\begin{array}{llll}5.97 & 0.899 & -0.841 & 0.49\end{array}$

I have acquired a unique experience after visiting the filming location.

Note: $\mathrm{SD}=$ Standard Deviation

$\begin{array}{llll}6.01 & 0.724 & -0.374 & 0.353\end{array}$

Table 5 below illustrates the mean differences between tourists' expectations of the Karen Blixen Museum and Samburu and their eventual experience. The findings revealed that tourists' experience exceeded their expectations in all the attributes under investigation. Specifically, the following were noted: the location of filming was perceived to be authentic; there was a higher similarity of scenes in Out of Africa and The White Maasai and the actual museum/site of filming; and finally, the information about the film location was true and that tourists were able to connect the movies The WhiteMaasai and Out of Africa storylines and the actual location experience.

Table 5: Mean Differences between Tourists' Expectations and Experience with Movie Setting.

\begin{tabular}{lccccc}
\hline Scale Item & $\begin{array}{c}\text { Mean } \\
\text { (Expect.) }\end{array}$ & $\begin{array}{c}\text { Mean } \\
\text { (Exper.) }\end{array}$ & $\begin{array}{c}\text { Std. } \\
\text { Error } \\
\text { Mean }\end{array}$ & T & Sig. \\
\hline $\begin{array}{l}\text { The filming locations/sites and objects used } \\
\text { in the movie should be authentic. }\end{array}$ & 5.09 & 5.65 & 0.098 & -4.73 & 0.000 \\
$\begin{array}{l}\text { I need to get as close as possible to the } \\
\text { filming locations. }\end{array}$ & 4.9 & 5.54 & 0.105 & -5.948 & 0.000 \\
$\begin{array}{l}\text { There should be similarity and resemblance } \\
\text { of scenes shown in Out of Africa and The }\end{array}$ & & & & & \\
\hline
\end{tabular}


White Maasai and the actual museum/site of filming.

5.7

0.118

$-2.875$

0.004

The overall site of the filming of Out of Africa and The White Maasai and the impressions in the museum/site should be very inspiring.

$\begin{array}{lllll}5.37 & 5.7 & 0.114 & -2.694 & 0.008\end{array}$

All information and facts about the museum/site should be true as it is depicted in the two movies Out of Africa and The White Maasai.

$\begin{array}{lllll}5.33 & 5.9 & 0.109 & -4.547 & 0.000\end{array}$

I should be able to relate the movies White Maasai Out of Africa's storylines and the actual location experience

I should acquire a unique experience

5.55

6.01

0.097

$-4.724 \quad 0.000$

Note : Expect. $=$ Expectation; Exper. $=$ Experience; Sig. $=$ Significance at 2 -tailed level.

The findings in the table 6 below indicates that location (mean $=3.87$ ) is the most important movie setting attribute affecting tourists' satisfaction, followed by image (mean = 3.77 ) and rituals (mean $=3.66)$ rural villages $($ mean $=3.23)$, artefacts (mean $=3.27$ ) and finally the language (mean $=3.28$ ). Movie attributes as location, image and rituals enable the setting to become a tourist destination and tap into the emotional/nostalgic tourist market. As such, the setting then benefits from an influx of movie-induced tourists and receives an economic boost and an improved or altered image in the minds of tourists.

Table 6: Displacement Attributes of Movie Setting.

\begin{tabular}{lllll}
\hline Attributes of the moviesetting & Mean & SD & Skewness & Kurtosis \\
\hline Physical attributes/image & 3.67 & 1.212 & -0.44 & -1.219 \\
Native inhabitants & 3.51 & 1.126 & -0.483 & -0.872 \\
Culture & 3.53 & 1.063 & -0.439 & -0.876 \\
Language & 3.28 & 1.126 & -0.029 & -1.163 \\
Rural villages & 3.23 & 1.216 & -0.036 & -1.282 \\
Souvenirs/ artefacts & 3.27 & 1.158 & -0.361 & -1.041 \\
Rituals & 3.66 & 0.896 & -0.722 & 0.086 \\
Location & 3.84 & 1.011 & -1.186 & 1.119 \\
Buildings & 3.43 & 1.155 & -0.582 & -0.445 \\
Image & 3.77 & 1.05 & -0.643 & -0.345 \\
\hline
\end{tabular}

Note: $\mathrm{n}=192$

\subsection{Reliability and Factor Loads}

The exploratory factor analyses were performed in order to test the assumptions for issues of dimensionality and convergent validity. There was a reasonable fit of the four-factor measurement model to the data. To test construct reliability, Cronbach's alpha coefficient was used. As presented in Table 1, the overall reliability for all scales exceeded the acceptable cutoff value of 0.60 , indicating that items were free from random error and internal consistency was adequate (Fornell \& Larcker, 1981). In order to test whether the distribution of values was adequate for conducting analysis, the Kaiser-Meyer-Olkin (KMO) measure of sampling adequacy was used and all constructs exceeded the threshold value of 0.50 as suggested by 
Field (2000). Therefore, the data was appropriate for conducting the factor analysis. In observing the commonalities, all item loadings were found to be significant following threshold of 0.50 recommended by Barclay et al. (1995).

Table 7: Factor Analysis and Reliability Results.

\begin{tabular}{|c|c|c|c|c|}
\hline Scale items & $\begin{array}{l}\begin{array}{l}\text { Factor } \\
\text { loadings }\end{array} \\
\end{array}$ & KMO & $\begin{array}{l}\% \text { of } \\
\text { Variance }\end{array}$ & Alpha \\
\hline Tourists' Expectations & & 0.658 & 62.799 & $\mathbf{0 . 8 3 1}$ \\
\hline The filming locations and objects should be authentic. & 0.834 & & & \\
\hline I need to get to/ closer to the real filming locations. & 0.726 & & & \\
\hline $\begin{array}{l}\text { There ought to be a resemblance of scenes depicted in Out of } \\
\text { Africa and the tangible museum where it was filmed. }\end{array}$ & 0.565 & & & \\
\hline $\begin{array}{l}\text { The general filming sites of The White Maasai and Out of } \\
\text { Africa should be very inspiring. }\end{array}$ & 0.773 & & & \\
\hline $\begin{array}{l}\text { The facts about the destination should be real as it is depicted } \\
\text { in the movies Out of Africa and The White Maasai. } \\
\text { I should be able to relate the movies The White Maasai and }\end{array}$ & 0.838 & & & \\
\hline Out of Africa's storylines and the actual location experience. & 0.894 & & & \\
\hline I should acquire a unique experience. & 0.719 & & & \\
\hline Experiences of Tourists & & 0.744 & 62.896 & 0.635 \\
\hline The location of filming and objects used are real. & 0.859 & & & \\
\hline $\begin{array}{l}\text { It is possible to get closer to the real filming location of a } \\
\text { movie. }\end{array}$ & 0.767 & & & \\
\hline There is a connection between the scenes Out of Africa and & & & & \\
\hline The White Maasai and the actual museum/site of filming. & 0.682 & & & \\
\hline $\begin{array}{l}\text { The filming site of Out of Africa and The White Maasai and } \\
\text { the impressions in the museum/site are very inspiring. }\end{array}$ & 0.561 & & & \\
\hline $\begin{array}{l}\text { The information and facts about the museum are real and } \\
\text { authentic as portrayed in Out of Africa and The White Maasai. } \\
\text { Ican connect between the movies Out of Africa and The White }\end{array}$ & 0.874 & & & \\
\hline Maasai's storyline and the actual location experience. & 0.847 & & & \\
\hline I have acquired a unique experience after visiting the filming & & & & \\
\hline location. & 0.779 & & & \\
\hline Displacement attributes of Movie Setting & & 0.807 & 72.283 & 0.754 \\
\hline Physical attributes/image & 0.805 & & & \\
\hline Native inhabitants & 0.722 & & & \\
\hline Culture & 0.783 & & & \\
\hline Language & 0.835 & & & \\
\hline Rural villages & 0.825 & & & \\
\hline Souvenirs/ artefacts & 0.635 & & & \\
\hline Rituals & 0.831 & & & \\
\hline Location & 0.754 & & & \\
\hline Buildings & 0.749 & & & \\
\hline Image & 0.800 & & & \\
\hline
\end{tabular}

\subsection{Hypothesis Testing}

The research findings showed that displacement of movie setting had coefficients of estimate $\left(\beta_{1}\right)$ of -0.477 (p-value $=0.000$ which is less than $\left.\alpha=0.05\right)$, which implies that for each unit increase in displacement of movie setting, there is 0.477 units decrease in satisfaction (Table 7). Based on the findings, the researcher rejected the null hypothesis and accepted that 
alternative hypothesis, meaning that displacement of movie setting has a significant effect on tourists' satisfaction.

Table 7: Regression Analysis Results.

\begin{tabular}{|c|c|c|c|c|c|}
\hline & \multicolumn{2}{|c|}{$\begin{array}{c}\text { Unstandardized } \\
\text { Coefficients }\end{array}$} & \multicolumn{3}{|c|}{ Standardized Coefficients } \\
\hline & $\mathbf{B}$ & Std. Error & Beta & $\bar{T}$ & Sig. \\
\hline (Constant) & 1.476 & 0.188 & & 7.873 & 0.000 \\
\hline Displacements & 0.644 & 0.052 & 0.666 & 12.291 & 0.00 \\
\hline $\mathrm{R}$ & $.666 a$ & & & & \\
\hline R Square & 0.443 & & & & \\
\hline Adjusted R Square & 0.44 & & & & \\
\hline Change Statistics & & & & & \\
\hline R Square Change & 0.443 & & & & \\
\hline F Change & 151.077 & & & & \\
\hline Sig. F Change & 0.000 & & & & \\
\hline
\end{tabular}

Note: a Dependent Variable: satisfaction.

\section{Conclusion, Implications and Limitations}

The aim of the study was to establish the effect of displacement of movie setting on tourists' satisfaction in movie induced tourism. The current study reveals that the displacement of the movie setting has a negative and significant effect on tourist satisfaction $\left(\beta_{1}=-0.477\right.$ (p-value $=0.000$ ), an indication that for each unit increase in displacement of movie setting, there is 0.477 units decrease in satisfaction.

The study's findings support Beeton (2005) findings that displacement is related to tourists' satisfaction since visitors to film sites are disappointed when they do not see exactly what was portrayed on the screen. Cognate to the study findings, Wang (2007) noted that tourists, who were aware of runaway productions and the differences between the movie set and reality, tended to have lower expectations and thus were more satisfied with their location visits compared to those that were unaware. Similarly, Beeton (2005) and Roesch (2009) both concluded that tourists are well aware of the differences between the locations in the movie and the real locations; therefore, they do not expect an authentic experience. In a similar vein, Iwashita (2006) argued that visitors can find the fulfilment of their emotional investment. As such, tourists are more likely to be disappointed if the location has been substituted or building no longer looks as they did in the movie. On his part, Beeton (2001) sited that when the location appears different than how it is portrayed in the film, there may be a loss of visitor satisfaction. This is because the appeal of tourist attraction is related to the image that the tourist brings with them. Therefore authenticity is important to film tourism especially when displacement occurs (Bolan et al., 2011). McIntosh (2004) reported that by authentic experience tourist are becoming 'personally involved in the experience', to experience the "natural context" and 'daily life', but also to experience 'facts, arts and crafts'. The study agrees with Chhabra (2010) and Kolar and Zabkar (2010) that authenticity is of pivotal significance in tourism setting since it is the primary attribute that brings the tourist and attraction component together.

For movie induced tourism to work and be used as a marketing strategy, the issue of runaway production should be discouraged by all actors involved; may it be directors, producers and various tourism organisations in a destination. This will indeed benefit many destinations that intend to use movies to promote its tourist attractions. Drawbacks of runaway production should also be carefully considered to avoid undesired misrepresentation of local's values, morals and interests. It is also worth noting from the study that, it is more important to visit locations portrayed in the movie rather than locations shown in the movies 
for one to be able to connect with the movie storyline and actual location experience. This brings sense and consistency with the original message and storyline.

Although this study was conducted in the Kenyan context, some general implications can be derived for theoretical literature on this topic that is not localised to the context of the study. From a theoretical perspective, this research provides an understanding of how movie induced tourism can influence customer satisfaction. This study also validates existing studies which argue that displacement of movie setting contributes significantly to customer satisfaction. Another implication of the study is that there are needs for government and relevant tourist sector stakeholders to accept and recognise film-induced tourism, and ensure greater collaboration in promoting and developing film locations as opposed to the story settings/places depicted, retention or re-creation of film sets if necessary to retain more essence of film authenticity. Movie induced tourism is becoming more popular, and many stakeholders can do more to make the best use of this phenomenon. To know which locations, people, themes and stories in films can affect destination image and induce tourism is valuable knowledge for tourist organisations, tour companies and local businesses. Such knowledge can be used by the key stakeholders in the sector to make a profit and also enhance repeat visit by the tourists.

The findings reported in the current paper should be considered in light of some study limitations. The cross-sectional design of the study was a limitation, which prevents the researcher to have causal deductions. Using longitudinal data from multiple sources in the future would be helpful in mitigating these concerns.

\section{References}

Akama, J. S. (2004). Neo-colonialism, Dependency and External Control of Africa's Tourism Industry.In C. M. Hall and H. Tucker (Eds.), Tourism and Post-colonialism. London: Taylor \& Francis.

Balon, P. \& Williams, L. (2008). The Role of Image in Service Promotion: Focusing on the Influence of Film on Consumer Choice within Tourism. International Journal of Consumer Studies, 32(4), 382-390.

Barclay, D.W., Thompson, R. \& Higgins, C. (1995). The partial least squares (PLS) approach to causal modeling: Personal computer adoption and use an illustration. Technology Studies, 2(2), pp.285-309.

Beeton, S. (2001). Smiling for the Camera: The Influence of Film Audiences on a Budget Tourism Destination.Tourism Culture and Communication, 3(1), 15-25.

Beeton, S. (2005). Film-Induced Tourism. Clevedon, UK: Channel View Publications.

Bigne', E., Sanchez, I. \& Sanz, S. (2005). Relationships among Residents' Image, Evaluation of the Stay, and Post-Purchase Behaviour.Journal of Vacation Marketing, 11(4), 291302.

Bolan, P., Boy, S. \& Bell, J. (2011). We've Seen it in the Movies, Let's See if it's True. Worldwide Hospitality and Tourism Themes, 3(2), $102-116$.

Bolan, P. \& Davidson, K. (2005).Film-Induced Tourism in Ireland: Exploring the Potential. Paper Presented at the Tourism \& Hospitality in Ireland Conference, University of Ulster, Coleraine, June.

Bolan, P., Boy, S. \& Bell, J. (2011). We have Seen it in the Movies, Let's See if it is True. Worldwide Hospitality and Tourism Themes, 3(2), 102-116.

Brand Kenya Board (2013). Kenya: Celebrating 50 Years of Independence. Kenya The Brand, No. 1, December.

Butler, R. (1990). The Influence of the Media in Shaping International Tourist Patterns.Tourism Recreation Research, 15(2), 46-55.

Chen, C. F., \& Chen, F. S. (2010). Experience, Quality, Perceived Value, Satisfaction and Behavioural Intentions for Heritage Tourists. Tourism Management, 31(1), 29-35. 
Chi, C. G., \& Qu, H. (2008). Examining the Structural Relationships of Destination Image, Tourist Satisfaction and Destination Loyalty: An Integrated Approach. Tourism Management, 29(4), 624-636.

Chhabra, D. (2005). Defining Authenticity and its Determinants: Toward an Authenticity Flow Model.Journal of Travel Research, 44(1), 64-73.

Chhabra, D. (2010). Back to the Past: A Sub-Segment of Generation Y's Perceptions of Authenticity. Journal of Sustainable Tourism, 18(6), 793-809.

Croy, W. G. \& Walker, R. D. (2003). Rural Tourism and Film: Issues for Strategic Regional Development. In D. Hall, L. Roberts, and M. Mitchell (Eds.), New Directions in Rural Tourism (115-33). Aldershot, UK: Ashgate Publishing Ltd.

Field, A. (2000). Discovering Statistics using SPSS for Windows. London, Thousand Oaks, New Delhi: Sage publications.

Gallorza, M. G. \& Saura, G. I. (2006). Value Dimensions, Perceived Value, Satisfaction and Loyalty: An Investigation of University Students' Travel Behaviour. Tourism Management, 27(3), 437-452.

Goulding, C. (2000). The Museum Environment and the Visitor Experience.European Journal of Marketing, 34(3/4), 261-278.

Government of Kenya, (2010).2009 Population and Housing Census Result. Nairobi: Kenya National Bureau of Statistics.

Gunn, C. A. (1998). VACATIONSCOPE: Designing Tourist Regions (2 ${ }^{\text {nd }}$ Ed.) New York: Van Nostrand Reinhold Company.

Hall, S. (1995). Hotel's Success Breeds Happy Employees, Hotel and Motel Management, 210(18), 3-5.

Heung, V. C. \& Cheng, E. (2000). Assessing Tourists' Satisfaction with Shopping in the Hong Kong Special Administrative Region of China. Journal of Travel Research, 38(4), 396-404.

Hudson, S. \& Ritchie, J. R. B. (2006). Promoting Destinations via Film Tourism: An Empirical Identification of Supporting Marketing Initiatives. Journal of Travel Research, 44, 387-396.

Iwashita, C. (2006). Media Representation of the UK as a Destination for Japanese Tourists. Tourist Studies, 6(1), 59-77.

Khan, A. H., Haque, A. \& Rahman, M. S. (2013). What Makes Tourists Satisfied? An Empirical Study on Malaysian Islamic Tourist Destination. Middle-East Journal of Scientific Research, 14, 1631-1637.

Kim, S. (2012). The Relationships of On-site Film-Tourism Experiences, Satisfaction, and Behavioral Intentions: The Case of Asian Audience's Responses to a Korean Historical TV Drama. Journal of Travel \& Tourism Marketing, 29(5), 472-484.

Kolar, T., \& Zabkar, V. (2010). A Consumer-Based Model of Authenticity: An Oxymoron or the Foundation of Cultural Heritage Marketing? Tourism Management, 31(5), 652664.

Kothari, C. R. (2004). Research Methodology: Methods\& Techniques. New Delhi: New Age International (P) Ltd.

Kozak, M., \& Rimmington, M. (2000). Tourist Satisfaction with Mallorca, Spain, as an OffSeason Holiday Destination. Journal of Travel Research, 38(3), 260-269.

McIntosh, A. J. (2004). Tourists' Appreciation of Maori Culture in New Zealand. Tourism Management, 25, 1-15.

Muchiri, J. (2013). Image Creation through Movies: A Case of "Out of Africa" and "The Constant Gardener" in Kenya. Informationand Knowledge Management, 3(3), 68.

Noel, B. S. (2009). Imaged or Imagined? Cultural Representations and the "Tourismification" of Peoples and Places. Cahiers d'études africaines, 193-194. 
Nunnally, J.C. (1978). Psychometric theory (2nd Ed.). New York: McGraw-Hill Book Company.

Phillips, D. M. \& Baumgartner, H. (2002). The Role of Consumption Emotions in the Satisfaction Response.Journal of Consumer Psychology, 12(3), 243-252.

Roesch, S. (2009). The Experiences of Film Location Tourists (Aspects of Tourism).Bristol, UK: Channel View Publications.

Rojas, C. \& Camarero, C. (2008). Visitors' Experience, Mood and Satisfaction in a Heritage Context: Evidence from an Interpretation Centre. Tourism Management, 29(3), 525537.

Santos, J. (1998). The Role of Tour Operators' Promotional Material in the Formation of Destination Image and Consumer Expectations: The Case of the People's Republic of China. Journal of Vacation Marketing, 4(3), 282-297.

Santos, J. \& Boote, J. (2003).A Theoretical Exploration and Model of Consumer Expectations, Post-Purchase Affective States and Affective Behavior. Journal of Consumer Behaviour, 3, 142-156.

Sellgren, E. (2011). Film-Induced Tourism: The Effect Films have on Destination Image Formation, Motivation and Travel Behaviour. Saarbrücken, Germany: LAP Lambert Academic Publishing.

Shandley, R., Jamal,T. \& Tanase, A.(2006).Location Shooting and the Filming Destination: Transylvanian Myths and the Post-Colonial Tourism Enterprise. Journal of Tourism and Cultural Change, 4(3), 137-58.

Tooke, N. \& Baker, M. (1996). Seeing is Believing: The Effect of Film on Visitor Numbers to Screened Locations. Tourism Management, 17(2), 87-94.

True Love Magazine, Dec/Jan 2005-2006 Issue No. 15, pp 68-73.

Wang, N. (1999). Rethinking Authenticity in Tourism Experience. Annals of Tourism Research, 26(2), 349-370.

Westbrook, R. A. \& Oliver, R. L. (1991).The Dimensionality of Consumption Emotion Patterns and Consumer Satisfaction. Journal of Consumer Research, 18(1), 84-91.

Yuksel, A. \& Rimmington, M. (1998). Tourist Satisfaction and Food Service Experience: Results and Implications of an Empirical Investigation. Anatolia, 9(1), 37-57.

Zeithaml, V. A., Berry, L. L., \& Parasuraman, A. (1993).The Nature and Determinants of Customer of Service.Journal of the Academy of Marketing Science, 21(1), 1-12.

Zeithaml, V. A., Parasuraman, A., \& Berry, L. L. (1990). Delivering Quality Service. New York, N.Y: The Free Press.

\section{Author Biography}

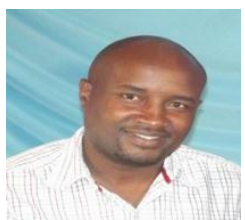

Justus Muchiri is a tourism management graduate, holder of MA Project Planning Management from University of Nairobi, Kenya and PhD in Tourism Management from Moi University, Kenya. Muchiri holds a permanent academic post at the school of Tourism and Natural Resource Management, Maasai Mara University. He is also a certified Quality Management System auditor by Kenya Bureau of Statistics. 


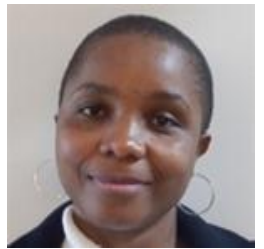

Rita Wairimu Nthiga is a Lecturer, Department of Hotel and hospitality Management, Moi University. She is a holder of a Masters in Hospitality and Tourism Management from Kenyatta University, Kenya and a $\mathrm{PhD}$ in Tourism, Conservation and Development from Wageningen University, The Netherlands. Her research interests are in Tourism, sustainable tourism and sustainable hospitality, conservation and development, hospitality operations management and contemporary issues in tourism and hospitality as well as tourism policy planning and policy analysis. She is currently the Head, Department of Hotel and Hospitality Management, Moi University and a Member of Tourism Professional Association (TPA). 